\title{
PREFERENSI RISIKO DAN FAKTOR-FAKTOR YANG MEMPENGARUHI KEPUTUSAN MASYARAKAT ILMIAH DALAM MENGONSUMSI PRODUK REKAYASA GENETIKA
}

\author{
Muhamad Agus Kurniawan', dan M. Rondhi ${ }^{2}$ \\ 1,2)Program Studi Agribisnis Fakultas Pertanian, Universitas Jember \\ Jl. Kalimantan No. 37 Jember, Jawa Timur, Indonesia \\ e-mail: 1)rondhi.faperta@unej.ac.id
}

(Diterima 23 Oktober 2019/Disetujui 26 November 2019)

\begin{abstract}
The purpose of this study was to find out: the perception of Genetically Modified Organisms (GMO) Products and preferences of risk consuming GMO as well as the factors that influence decisions of the scientific community in consuming GMO. This research used descriptive and analytic method. Determination of the area by purposive method at the University of Jember. Method of determining the sample uses purposive sampling, namely students and lecturers from the Public Health Faculty and Agriculture Faculty. Furthermore, determining the number of samples using quota sampling, 150 students and 90 lecturers. The method of collecting survey data using questionnaires and data were analyzed based on questionnaires that returned and were responded to as many as 120 for students and 30 for lecturers. The results of the study show that (1) public perceptions regarding GMO based on health and agriculture are agreed, while the economy is hesitant. (2) risk of preference majority of the scientific community is a risk lover, which is as many as 80 people. (3) Factors that influence the scientific community's decision to consume GMO products significantly, type of work, age, amount of allowance or income per month, daily food expenditure, knowledge level and risk aversion level.
\end{abstract}

Keywords: GMO, risk aversion level, risk preference

\begin{abstract}
ABSTRAK
Tujuan Penelitian ini untuk mengetahui persepsi terhadap Produk Rekayasa Genetik (PRG), preferensi risiko dan faktor-faktor yang mempengaruhi keputusan masyarakat ilmiah dalam mengonsumsi PRG. Penelitian ini menggunakan metode deskriptif dan analitik. Penentuan lokasi penelitian di Unviversitas Jember menggunakan purposive method. Metode penentuan sampel menggunakan purposive sampling, yaitu mahasiswa dan dosen dari Fakultas Kesehatan Masyarakat dan Pertanian. Penentuan sampel menggunakan quota sampling yaitu sebanyak 120 mahasiswa dan 30 dosen. Hasil penelitian menunjukkan bahwa (1) persepsi masyarakat terhadap PRG berdasarkan aspek lingkungan pertanian dan kesehatan mereka setuju, sedangkan berdasarkan aspek ekonomi mereka masih ragu-ragu, (2) Sebanyak 80 responden memiliki sifat risk lover terhadap PRG, (3) Faktor-faktor yang mempengaruhi masyarakat ilmiah dalam mengonsumsi PRG secara signigikan yaitu: jenis pekerjaan, umur, pendapatan rumah tangga atau jumlah uang saku per bulan, pengeluaran untuk kebutuhan pangan per hari, tingkat pengetahuan dan risk aversion level.
\end{abstract}

Kata kunci: PRG, risk aversion level, preferensi risiko

\section{PENDAHULUAN}

Menurut Carletto et al, (2013), dimensi ketersediaan pangan merujuk pada ketersediaan pangan dalam jumlah yang cukup dengan kualitas yang sesuai dan dipasok melalui produksi dalam negeri atau impor.
Berbagai upaya telah dilakukan untuk meningkatkan ketersediaan pangan mengandalkan produksi dalam negeri antara lain intensifikasi dan ekstensifikasi. Namun, upaya tersebut belum cukup untuk mengejar laju kebutuhan pangan yang terus meningkat. Hal itu diperparah dengan meningkatnya 
konversi lahan pertanian. Laju konversi lahan ke-non pertanian seluas 96.512 hektare per tahun (Mulyani et al., 2016). Sehingga diperlukan upaya untuk memenuhi kebutuhan pangan salah satunya melalui penggunaan bioteknologi.

Menurut Bennet (1998), menyatakan bahwa bioteknologi merupakan integrasi pemanfaatan biochemistry, microbiology dan rekayasa genetika untuk menciptakan suatu industri (teknologi) yang memiliki kemampuan dalam bidang mikro organisme dan jaringan agar bermanfaat bagi manusia. Bioteknologi diharapkan mampu menyelesaikan berbagai masalah khususnya dalam hal pemenuhan kebutuhan pangan serta meningkatkan kesejahteraan para petani (ISAAA, 2017). Rekayasa genetika adalah salah satu bentuk bioteknologi yang dilakukan dengan memodifikasi gen dari suatu makhluk hidup, terutama DNA dan transformasi gen tertentu untuk menciptakan variasi yang baru. Adanya manipulasi DNA memungkinkan untuk memasukkan sifat dari hampir semua organisme pada tanaman.

Perkembangan pemanfaatan teknologi rekayasa genetika telah menghasilkan produk rekayasa genetik yang memiliki sifat-sifat baru yang diinginkan untuk mengatasi kendala dalam memenuhi kebutuhan pangan yang lebih berkualitas serta bersaing (Siregar, 2012). Menurut ISAAA (2017), luas areal penanaman Produk Rekayasa Genetika (PRG) di dunia cenderung mengalami kenaikan dari tahun ke tahun. Negara penanam PRG terbesar di dunia ditempati oleh Amerika Serikat. Menurut ISAAA (2017), Indonesia berhenti menjadi negara penanam PRG dan beralih sebagai negara pengimpor PRG.

Pemerintah Indonesia menggunakan Peraturan Pemerintah 21/2005 tentang Keamanan Hayati PRG, yang membutuhkan sistem pengawasan dan pengendalian yang ketat untuk mengatur benih PRG yang disetujui. Sebagai hasilnya, penanaman komersial dari tanaman rekayasa genetika varietas jagung dan kedelai di Indonesia tertahan sampai saat ini (Slette dan Rahayu, 2013). Menurut Shew et al. (2016), penggunaan teknologi rekayasa genetika mampu menciptakan tanaman yang tahan terhadap cekaman lingkungan serta meningkatkan produksi.

Kemunculan PRG mampu memenuhi permintaan kebutuhan pangan khususnya kedelai, tetapi di sisi lain produk tersebut mungkin memiliki potensi sisi buruk dalam jangka waktu yang panjang. Menurut Smith (2011), menyatakan bahwa terjadi kenaikan penyakit kronis dari 7\% ke 13\% dalam 9 tahun di AS sejak GMO diperkenalkan pada tahun 1996. Kasus yang pernah terjadi adalah tanaman transgenik yang menghasilkan kapas dan mengandung gen Bt akan membuat yield yang dihasilkan meningkat. Sementara itu, pada penelitian lain, jagung transgenik yang mengandung gen Bt menyebabkan kematian larva monarch dan efek buruk terhadap perkembangan, berat badan, serta perilaku kupu kupu (Prasifka et al, 2007). Munculnya beberapa kasus dampak buruk akibat PRG akan membuat masyarakat khawatir, sehingga keberadaan PRG di masyarakat masih menjadi kontroversi. Hal tersebut dikarenakan informasi ilmiah masih dianggap belum cukup untuk membuat penilaian risiko terhadap perkembangan tanaman PRG di Indonesia. Sehingga perlu dilakukan penelitian terkait informasi tersebut.

Penelitian yang pernah dilakukan terkait PRG antara lain oleh Saragih et al. (2009) terkait faktor-faktor penentu adopsi benih jagung transgenik. Penelitian lain juga pernah dilakukan oleh Hidayat (2014) dan Artanti et al. (2010) terkait persepsi dan faktor-faktor penerimaan petani terhadap PRG. Penelitian sebelumnya belum ada yang membahas preferensi risiko dan faktor-faktor yang mempengaruhi keputusan dalam mengonsumi PRG.

Penelitian tentang produk rekayasa genetika terutama pangan sangatlah penting untuk dilakukan. Hal ini dikarenakan Peredaran PRG sudah mulai meluas di masyarakat sedangkan PRG masih dianggap sebagai barang yang berisiko dan menimbulkan kontroversi. Menurut ISAAA (2017), Indonesia termasuk dalam salah satu negara pengimpor PRG. Sehingga perlunya penelitian terkait 
persepsi masyarakat dan perilaku masyarakat dalam menghadapi risiko dari PRG. Dalam penelitian ini tidak terbatas hanya mengetahui persepsi masyarakat terhadap PRG dan faktor-faktor yang mempengaruhi dalam mengonsumsi PRG tetapi juga bertujuan mengetahui perilaku masyarakat dalam menghadapi resiko. Penelitian ini diharapkan mampu memberikan gambaran bagaimana persepsi serta perilaku masyarakat terhadap adanya PRG.

Adapun tujuan dari penelitian ini adalah untuk mengetahui : (1) persepsi masyarakat ilmiah terhadap PRG (2) preferensi risiko masyarakat ilmiah dalam mengonsumsi PRG dan (3) faktor-faktor yang mempengaruhi keputusan masyarakat ilmiah dalam mengonsumsi PRG.

\section{METODE}

Penelitian ini difokuskan pada masyarakat ilmiah untuk mengetahui preferensi risiko pada Produk Rekayasa Genetika. Masyarakat ilmiah yang diteliti adalah masyarakat ilmiah yang ada di lingkungan Universitas Jember dengan pertimbangan bahwa Universitas Jember menjadi satu satunya perguruan tinggi di Jember yang berperan aktif dalam pengembangan bioteknologi di Indonesia (Prianto dan Yudhasasmita, 2017). Sehingga dapat merepresentasikan masyarakat ilmiah yang ada di Kabupaten Jember. Penelitian ini menggunakan metode deskriptif dan analitik.

Metode pengambilan contoh menggunakan purposive sampling dan quota sampling. Responden dalam penelitian ini adalah masyarakat ilmiah di Universitas Jember yang terdiri dari dosen dan mahasiswa pada keilmuan Fakultas Kesehatan Masyarakat dan Fakultas Pertanian. Hal itu dikarenakan keterkaitan dari adanya PRG yang mendapat dampak paling besar adalah bidang keilmuan lingkungan pertanian, kesehatan dan ekonomi. Selain itu, kedua Fakultas tersebut merupakan representasi dari masyarakat ilmiah yang memahami produk rekayasa geneteik. Responden yang menjadi sampel dalam penelitian ini adalah mahasiswa dan dosen dari PS Agribisnis, PS Agroteknologi dan Fakultas Kesehatan Masyarakat.

Berdasarkan tujuan penelitian, maka ditentukan sampling yang dipilih adalah mahasiswa yang sedang menempuh semester 8 dan dosen dari bidang keilmuan Agroteknologi, Agribisnis dan Kesehatan Masyarakat. Pertimbangan selanjutnya adalah sampel yang bersedia menjadi responden dalam penelitian ini dan sudah memiliki pengetahuan tentang PRG. Tahap selanjutnya yaitu quota sampling sehingga diperoleh sampel setiap kelompok responden mahasiswa masing-masing diambil sebanyak 50 orang, sedangkan untuk dosen diambil sebanyak 30 orang.

Sebanyak 240 kuesioner dicetak dan disebarkan kepada responden. Jumlah responden yang dianalisis adalah kuesioner yang kembali kepada peneliti atau disebut response rate. Peneliti tidak hanya menyebar kuesioner melalui media offline maupun online, tetapi juga menghubungi responden agar berkenan mengisi kuesioner yang sudah disebarkan.

Blair dan Inniss (2011) menyatakan bahwa rata-rata response rate melalui kuesioner sebesar $54,4 \%$. Sedangkan rata-rata response rate melalui survey online sebesar 53,9\%. Secara umum, semakin tinggi probabilitas response rate maka akan semakin tinggi kemungkinan mendapatkan sampel yang representatif. Pada penelitian ini kuesioner yang kembali sebanyak 150 kuesioner dari 240 kuesioner sehingga response rate dihasilkan sebesar $62,5 \%$.

Persepsi masyarakat ilmiah terhadap produk rekayasa genetika dijawab dengan metode deskriptif menggunakan skala likert. Jawaban setiap instrument item yang menggunakan skala likert mempunyai gradasi dari sangat negatif sampai sangat positif, pengukuran persepsi diukur menggunakan skala likert yang terdiri dari lima peringkat: 1 (sangat tidak setuju), 2 (tidak setuju), 3 (raguragu), 4 (setuju), 5 (sangat setuju).

Persepsi masyarakat ilmiah terhadap risiko mengonsumsi produk rekayasa gene- 
tika ditentukan berdasarkan skor. Nilai total skor dihitung pada setiap pernyataan dari 150 responden untuk disesuaikan berdasarkan interval skor. Berdasarkan perhitungan total skor maka kategori penilaian persepsi berdasarkan interval skor sebagai berikut:

$1,00-1,79=$ Sangat tidak Setuju

$1,80-2,59=$ Tidak Setuju

$2,60-3,39=$ Ragu-ragu

$3,40-4,19=$ Setuju

$4,20-5,00$ = Sangat Setuju

Preferensi risiko masyarakat ilmiah dalam mengonsumsi PRG diperoleh melalui pendekatan secara eksperimen. Responden diberikan beberapa pilihan pada setiap kejadian pada suatu simulasi, simulasi yang digunakan mengadopsi dari penelitian Holt dan Laury (1980) dengan menggunakan metode multiple price list. Berikut metode multiple price list yang telah dimodifikasi pada Tabel 1.

Responden diharuskan memilih Opsi A atau Opsi B pada setiap baris keputusan. Kriteria penentuan preferensi risiko responden dilihat dari pada keputusan nomor berapa responden beralih dari opsi A ke opsi B. Setelah diketahui perpindahannya, maka melihat pada keputusan terakhir saat responden memilih opsi A. Setelah melihat pada baris ke berapa responden berpindah, tahap selanjutnya menentukan preferensi risiko responden melalui tabel klasifikasi risk aversion level.

Langkah selanjutnya melihat nilai tengah dari range of relative risk aversion pada Tabel 2. Jika nilai tengah yang didapatkan kurang dari nol maka preferensi risiko masyarakat ilmiah digolongkan dalam risk lover, jika nilai tengah sama dengan nol maka masyarakat ilmiah digolongkan dalam risk neutral sedangkan jika nilai tengah lebih dari nol maka masyarakat ilmiah digolongkan dalam risk averse.

Tabel 2. Klasifikasi Risk Aversion Level

\begin{tabular}{ccc}
\hline No & Range of Relative Risk Aversion \\
\hline $0-1$ & & $\mathrm{r} \quad-0,95$ \\
2 & $-0,95<\mathrm{r}<-0,49$ \\
3 & $-0,49<\mathrm{r}<-0,15$ \\
4 & $-0,15<\mathrm{r}<0,15$ \\
5 & $0,15<\mathrm{r}<0,41$ \\
6 & $0,41<\mathrm{r}<0,68$ \\
7 & $0,68<\mathrm{r}<0,97$ \\
8 & $0,97<\mathrm{r}<1,37$ \\
$9-10$ & $1,37<\mathrm{r}$ \\
\hline
\end{tabular}

Sumber: Holt and Laury (1980)

Pengukuran untuk mengetahui preferensi risiko dilakukan secara terpisah berdasarkan kelompok keilmuan kesehatan, ling-

Tabel 1. Tabel Pilihan Multiple Price List

\begin{tabular}{|c|c|c|}
\hline Keputusan & Probabilitas Keputusan Pilihan A & Probabilitas Keputusan Pilihan B \\
\hline 1 & $\begin{array}{l}10 \% \text { dapat } \operatorname{Rp} 600.000 \\
90 \% \text { dapat } \operatorname{Rp} 480.000\end{array}$ & $\begin{array}{c}10 \% \text { dapat } \operatorname{Rp} 1.115 .000 \\
90 \% \text { dapat } \operatorname{Rp} 300.000\end{array}$ \\
\hline 2 & $\begin{array}{l}20 \% \text { dapat } \operatorname{Rp} 600.000 \\
80 \% \text { dapat } \operatorname{Rp} 480.000\end{array}$ & $\begin{array}{l}20 \% \text { dapat } \operatorname{Rp} 1.115 .000 \\
80 \% \text { dapat } \operatorname{Rp} 300.000\end{array}$ \\
\hline 3 & $\begin{array}{l}30 \% \text { dapat } \operatorname{Rp} 600.000 \\
70 \% \text { dapat } \operatorname{Rp} 480.000\end{array}$ & $\begin{array}{l}30 \% \text { dapat } \operatorname{Rp} 1.115 .000 \\
70 \% \text { dapat } \operatorname{Rp} 300.000\end{array}$ \\
\hline 4 & $\begin{array}{l}40 \% \text { dapat } \operatorname{Rp} 600.000 \\
60 \% \text { dapat } \operatorname{Rp} 480.000\end{array}$ & $\begin{array}{l}40 \% \text { dapat } \operatorname{Rp} 1.115 .000 \\
60 \% \text { dapat } \operatorname{Rp} 300.000\end{array}$ \\
\hline 5 & $\begin{array}{l}50 \% \text { dapat } \operatorname{Rp} 600.000 \\
50 \% \text { dapat } \operatorname{Rp} 480.000\end{array}$ & $\begin{array}{l}50 \% \text { dapat } \operatorname{Rp} 1.115 .000 \\
50 \% \text { dapat } \operatorname{Rp} 300.000\end{array}$ \\
\hline 6 & $\begin{array}{l}60 \% \text { dapat } \operatorname{Rp} 600.000 \\
40 \% \text { dapat } \operatorname{Rp} 480.000\end{array}$ & $\begin{array}{l}60 \% \text { dapat } \operatorname{Rp} 1.115 .000 \\
40 \% \text { dapat } \operatorname{Rp} 300.000\end{array}$ \\
\hline 7 & $\begin{array}{l}70 \% \text { dapat } \operatorname{Rp} 600.000 \\
30 \% \text { dapat } \operatorname{Rp} 480.000\end{array}$ & $\begin{array}{l}70 \% \text { dapat } \operatorname{Rp} 1.115 .000 \\
30 \% \text { dapat } \operatorname{Rp} 300.000\end{array}$ \\
\hline 8 & $\begin{array}{l}80 \% \text { dapat } \operatorname{Rp} 600.000 \\
20 \% \text { dapat } \operatorname{Rp} 480.000\end{array}$ & $\begin{array}{l}80 \% \text { dapat } \operatorname{Rp} 1.115 .000 \\
20 \% \text { dapat } \operatorname{Rp} 300.000\end{array}$ \\
\hline 9 & $\begin{array}{l}90 \% \text { dapat } \operatorname{Rp} 600.000 \\
10 \% \text { dapat } \operatorname{Rp} 480.000\end{array}$ & $\begin{array}{l}90 \% \text { dapat } \operatorname{Rp} 1.115 .000 \\
10 \% \text { dapat } \operatorname{Rp} 300.000\end{array}$ \\
\hline 10 & $100 \%$ dapat $\operatorname{Rp} 600.000$ & $100 \%$ dapat Rp 1.115.000; \\
\hline
\end{tabular}

Sumber: Holt and Laury (1980) 
kungan pertanian dan ekonomi. Hal tersebut bertujuan untuk mengetahui sudut pandang dari bidang keilmuan yang berbeda dalam menyikapi risiko yang ada pada PRG.

Faktor-faktor yang mempengaruhi pengambilan keputusan masyarakat ilmiah dalam mengonsumsi PRG di Kabupaten Jember dianalisis menggunakan pendekatan Linear Probability Model (LPM). Formulasi persamaan yang diterapkan adalah sebagai berikut:

$$
Y i=\frac{e^{\beta_{0}+\beta_{1} x_{1}+\beta_{2} x_{2}+\beta_{3} x_{3}+\beta_{4} x_{4}+\beta_{5} x_{5}+\beta_{6} D_{1}+\beta_{7} D_{2}}}{1+e^{\beta_{0}+\beta_{1} x_{1}+\beta_{2} X_{2}+\beta_{3} X_{3}+\beta_{4} x_{4}+\beta_{5} x_{5}+\beta_{6} D_{1}+\beta_{7} D_{2}}}
$$

\section{Keterangan:}

$\mathrm{Yi}=$ Keputusan masyarakat ilmiah untuk mengonsumsi PRG

1 = Jika Masyarakat Ilmiah bersedia mengonsumsi PRG

$0=$ Jika Masyarakat Ilmiah tidak bersedia mengonsumsi PRG

$\beta 0 \quad=$ konstanta

$\beta 1-\beta 7=$ koefisien regresi variabel independen

$\mathrm{X}_{1}=$ Usia (Tahun)

$\mathrm{X}_{2}=$ Tingkat Pengetahuan

$\mathrm{X}_{3}=$ Besar pengeluaran untuk pangan (Rp/hari)

$\mathrm{X}_{4} \quad=$ Pendapatan (Rupiah)

$\mathrm{X}_{5} \quad=$ Risk Aversion Level

$\mathrm{D}_{1} \quad=$ Jenis Kelamin $(0=$ Perempuan dan 1 = Laki-laki)

$\mathrm{D}_{2}=$ Pekerjaan $(0=$ Mahasiswa dan $1=$ Dosen)

\section{HASIL DAN PEMBAHASAN}

\section{PERSEPSI MASYARAKAT ILMIAH}

\section{Persepsi Masyarakat Ilmiah terhadap PRG} Berdasarkan Aspek Keilmuan Kesehatan

Tabel 3 menunjukkan bahwa mayoritas responden memberikan respon setuju terhadap pernyataan-pernyataan terkait rekayasa genetika berdasarkan aspek keilmuan kesehatan. Rata-rata skor tertinggi yaitu pada pernyataan "Mengonsumsi pangan berformalin lebih berbahaya dibandingkan mengonsumsi PRG", dengan sebanyak $44 \%$ dari keseluruhan responden memberi nilai 5 pada pernyataan tersebut. Menurut responden formalin memang tidak diperuntukkan untuk ditambahkan pada bahan pangan, tetapi digunakan untuk pengawetan dan dampak yang ditimbulkan terhadap manusia yang mengonsumsi pangan berformalin adalah dampak yang negatif. Setiawan et al. (2018) menyatakan bahwa mengonsumsi makanan yang mengandung formalin dapat mengakibatkan iritasi pada saluran pernapasan, serta mengganggu fungsi hati, ginjal, dan sistem reproduksi. Sedangkan dampak negatif dari mengonsumsi produk hasil rekayasa genetika masih belum ditemukan hingga saat ini.

Tabel 3. Rata-rata Skor Persepsi Masyarakat Ilmiah terhadap Produk Rekayasa Genetika Berdasarkan Aspek Kesehatan

\begin{tabular}{|c|c|c|c|c|c|}
\hline No & Pernyataan & $\begin{array}{c}\text { Rata-rata } \\
\text { Skor }\end{array}$ & Modus & $\begin{array}{l}\text { Presentase } \\
\text { Modus (\%) }\end{array}$ & Keterangan \\
\hline 1 & $\begin{array}{l}\text { Pangan PRG berpotensi } \\
\text { memberikan nutrisi yang lebih } \\
\text { baik }\end{array}$ & 3,73 & 4 & 38,67 & Setuju \\
\hline 2 & $\begin{array}{l}\text { Pangan PRG menggunakan lebih } \\
\text { sedikit bahan kimia, yang } \\
\text { membuat makanan lebih aman }\end{array}$ & 2,95 & 3 & 38 & Ragu-ragu \\
\hline 3 & $\begin{array}{l}\text { Mengonsumsi pangan } \\
\text { berformalin lebih berbahaya } \\
\text { dibandingkan mengonsumsi } \\
\text { PRG }\end{array}$ & 4,17 & 5 & 44 & Setuju \\
\hline 4 & $\begin{array}{l}\text { Pangan PRG berpotensi } \\
\text { menimbulkan penyakit baru } \\
\text { pada manusia }\end{array}$ & 2,82 & 3 & 29,33 & Ragu-ragu \\
\hline & Rataan Skor & 3,42 & & & Setuju \\
\hline
\end{tabular}

Sumber: Data Primer diolah (2019) 
Pernyataan yang mengatakan "Pangan PRG berpotensi menimbulkan penyakit baru pada manusia" mendapat rata-rata skor terendah sebesar 2,82 dengan sebanyak 29,33\% sampel memberi nilai 3 pada pernyataan tersebut. Menurut responden memang pernah terjadi beberapa kasus yang diberitakan seperti ditariknya apel impor dari Amerika Serikat dikarenakan adanya kandungan suatu bakteri. Tetapi sampai masih belum ada penelitian ilmiah yang mampu membuktikan bahwa produk hasil rekayasa genetika memberikan dampak negatif pada tubuh manusia yang mengonsumsinya.

\section{Persepsi Masyarakat Ilmiah terhadap PRG Berdasarkan Aspek Keilmuan Lingkungan Pertanian}

Berdasarkan Tabel 4 bahwa mayoritas responden memberikan respon setuju terhadap pernyataan rekayasa genetika berdasarkan aspek lingkungan pertanian. Pernyataan "Teknologi rekayasa genetika mampu mengatasi permasalahan dalam pemenuhan kebutuhan pangan" mendapat rata-rata skor tertinggi sebesar 3,70 dengan sebanyak $46,67 \%$ dari keseluruhan sampel memberikan nilai 4 pada pernyataan tersebut. Menurut responden dengan hadirnya rekayasa genetika manusia mampu memodifikasi sifat dari suatu tanaman sesuai dengan kebutuhan atau tujuannya

Pernyataan yang mengatakan "Tanaman PRG berpotensi menimbulkan gangguan pada ekosistem sekitar" mendapat rata-rata skor sebesar 3,16 dengan sebanyak 40\% responden memberi nilai 3 pada pernyataan tersebut. Beberapa penelitian menunjukkan bahwa adanya aliran genetik di tanah yang mempengaruhi mikroba tanah akibat dari penanaman tanaman rekayasa genetika. Menurut Messeguer (2003) aliran gen dari tanaman transgenik ke lingkungan menjadi salah satu efek yang harus diperhitungkan, karena hal tersebut bisa berakibat baik atau buruk terhadap lingkungan sekitarnya.

Tabel 4. Rata-rata Skor Persepsi Masyarakat Ilmiah terhadap Produk Rekayasa Genetika Berdasarkan Aspek Lingkungan Pertanian

\begin{tabular}{clcccc}
\hline No & \multicolumn{1}{c}{ Pernyataan } & $\begin{array}{c}\text { Rata-rata } \\
\text { Skor }\end{array}$ & Modus & $\begin{array}{c}\text { Presentase } \\
\text { Modus (\%) }\end{array}$ & Keterangan \\
\hline 1 & $\begin{array}{l}\text { Produktivitas tanaman PRG } \\
\text { lebih tinggi dibandingkan } \\
\text { dengan tanaman lokal }\end{array}$ & 3,68 & 4 & 47,33 & Setuju \\
2 & $\begin{array}{l}\text { Munculnya teknologi } \\
\text { rekayasa genetika dapat } \\
\text { menghilangkan plasma } \\
\text { nutfah yang ada }\end{array}$ & 3,54 & 3 & 30,67 & Setuju \\
3 & $\begin{array}{l}\text { Tanaman PRG tahan } \\
\text { terhadap cekaman } \\
\text { lingkungan }\end{array}$ \\
4 & $\begin{array}{l}\text { Tanaman PRG lebih sedikit } \\
\text { dalam penggunaan pestisida } \\
\text { Teknologi rekayasa genetika } \\
\text { mampu mengatasi } \\
\text { permasalahan dalam } \\
\text { pemenuhan kebutuhan } \\
\text { pangan }\end{array}$ & 3,18 & 3 & 43,33 & Ragu-ragu \\
\hline $\begin{array}{l}\text { Tanaman PRG berpotensi } \\
\text { menimbulkan gangguan } \\
\text { pada ekosistem sekitar }\end{array}$ & 3,70 & 4 & 46,67 & Setuju \\
\hline$\quad$ Rataan Skor & 3,48 & 3 & 40 & Ragu-ragu \\
\hline
\end{tabular}

Sumber: Data Primer diolah (2019) 


\section{Persepsi Masyarakat Ilmiah terhadap PRG Berdasarkan Aspek Keilmuan Ekonomi}

Berdasarkan Tabel 5 diketahui mayoritas responden memberikan respon yang raguragu terhadap pernyataan-pernyataan terkait rekayasa genetika berdasarkan aspek keilmuan ekonomi. Pernyataan terkait "Secara umum, pengggunaan teknologi rekayasa genetika akan memberikan keuntungan pada industri pertanian dan industri makanan" mendapat rata-rata skor tertinggi dimana sebanyak $54 \%$ dari total responden memberikan nilai 4 pada pernyataan tersebut. Menurut responden adanya teknologi rekayasa genetika memungkinkan untuk memodifikasi tanaman agar memiliki sifat yang lebih baik dibanding produk yang sudah ada. Pada industri pertanian salah satu contohnya adalah PT M. Perusahaan tersebut merupakan perusahaan multinasional yang bergerak di bidang pengembangan benih rekayasa genetika maupun benih hibrida.

Pernyataan yang mengatakan "Produk Rekayasa Genetika memberikan harga yang lebih murah" dimana sebanyak 58\% dari keseluruhan sampel memberikan nilai 3 pada pernyataan tersebut. Hal tersebut karena harga benih hasil rekayasa genetika lebih mahal dibandingkan dengan benih lokal yang ada dikarenakan biaya penelitian dan pengembangan dari benih rekayasa genetika yang besar sehingga biaya tersebut mungkin saja dibebankan kepada konsumen.

\section{PREFERENSI RISIKO MASYARAKAT ILMIAH DALAM MENGONSUMSI PRODUK REKAYASA GENETIKA DI KABUPATEN JEMBER}

Adanya PRG diharapkan mampu memenuhi kebutuhan pangan di masyarakat sehingga tidak terjadi kelangkaan bahan pangan yang menyebabkan meningkatnya harga pangan secara drastis. Tetapi di sisi lain sampai saat ini masih belum ada penelitian yang mampu membuktikan secara ilmiah bahwa adanya rekayasa genetika memberikan dampak yang baik ataupun buruk terhadap lingkungan maupun kesehatan.

Produk hasil rekayasa genetika memiliki resiko yang lebih tinggi bila dibandingkan produk non rekayasa genetika. Dampak dari produk rekayasa genetika terhadap lingkungan maupun kesehatan yang masih menjadi kontroversi menjadi salah satu

Tabel 5. Rata-rata Skor Persepsi Masyarakat Ilmiah terhadap Produk Rekayasa Genetika Berdasarkan Aspek Ekonomi

\begin{tabular}{|c|c|c|c|c|c|}
\hline No & Pernyataan & $\begin{array}{c}\text { Rata-rata } \\
\text { Skor }\end{array}$ & Modus & $\begin{array}{l}\text { Presentase } \\
\text { Modus (\%) }\end{array}$ & Keterangan \\
\hline 1 & $\begin{array}{l}\text { Secara umum, penggunaan } \\
\text { teknologi rekayasa genetika } \\
\text { akan memberikan } \\
\text { keuntungan pada industri } \\
\text { pertanian dan industri } \\
\text { makanan }\end{array}$ & 3,82 & 4 & 54 & Setuju \\
\hline 2 & $\begin{array}{l}\text { Produk Rekayasa Genetika } \\
\text { memberikan harga yang } \\
\text { lebih murah }\end{array}$ & 3 & 3 & 58 & Ragu-ragu \\
\hline 3 & $\begin{array}{l}\text { Penanaman tanaman PRG } \\
\text { dapat meningkatkan } \\
\text { pendapatan petani }\end{array}$ & 3,39 & 4 & 60 & Ragu-ragu \\
\hline 4 & $\begin{array}{l}\text { Penanaman tanaman PRG } \\
\text { mampu menurunkan biaya } \\
\text { produksi }\end{array}$ & 3,23 & 3 & 61 & Ragu-ragu \\
\hline & Rataan Skor & 3,36 & & & Ragu-ragu \\
\hline
\end{tabular}


pertimbangan masyarakat ilmiah dalam menentukan keputusan. Ditambah lagi masih kurangnya sosialisasi terkait perkembangan produk rekayasa genetika terhadap masyarakat luas. Maka hal tersebut mempengaruhi preferensi masyarakat ilmiah dalam menentukan keputusan.

Berdasarkan hasil analisis, maka seluruh masyarakat ilmiah yang menjadi responden dapat digolongkan preferensinya terhadap risiko seperti pada Tabel 6. Masyarakat ilmiah yang memiliki sifat menyukai risiko didominasi oleh responden yang bersedia mengonsumsi produk rekayasa genetika sebanyak 67 orang atau $83,75 \%$ sedangkan sisanya 13 orang atau $16,25 \%$ memilih tidak bersedia mengonsumsi produk rekayasa genetika. Masyarakat ilmiah yang memiliki sifat netral terhadap risiko sebanyak 4 orang atau $40 \%$ bersedia mengonsumsi produk rekayasa genetika dan sisanya sebanyak 6 orang atau $60 \%$ tidak bersedia mengonsumsi produk rekayasa genetika.

Responden yang memiliki sifat menghindari risiko sebanyak 26 orang atau 43,33\% bersedia mengonsumsi produk rekayasa genetika, sedangkan sisanya sebanyak 34 orang atau $56,67 \%$ tidak bersedia mengonsumsi produk rekayasa genetika. Mayoritas masyarakat ilmiah di Kabupaten Jember memilih untuk menyukai risiko. Hal itu dikarenakan saat ini produk rekayasa genetika sudah beredar luas di pasaran. Peneliti juga ingin mengetahui preferensi risiko berdasarkan kelompok responden yang berbeda.

Distribusi risk preference responden mahasiswa agroteknologi dapat dilihat pada Tabel 7. Mahasiswa yang memiliki sifat menyukai risiko mayoritas bersedia mengonsumsi produk rekayasa genetika sebanyak 15 orang atau $88,23 \%$ sedangkan sisanya 2 orang atau $11,67 \%$ tidak bersedia mengonsumsinya. Sebanyak 8 orang yang memiliki sifat netral terhadap risiko cenderung bersedia untuk mengonsumsi produk rekayasa genetika sebanyak 7 orang atau $87,5 \%$ sedangkan 1 orang atau $12,5 \%$ tidak bersedia untuk mengonsumsi.

Mahasiswa agroteknologi yang memiliki sifat menghindari risiko sebanyak 15 orang atau $100 \%$ tidak bersedia mengonsumsi produk rekayasa genetika. Sedangkan mahasiswa yang menghindari risiko sebanyak 15 orang seluruhnya memilih bersedia mengonsumsi produk rekayasa genetika.

Tabel 6. Distribusi Risk Preference Masyarakat Ilmiah dalam Mengonsumsi Produk Rekayasa Genetika di Kabupaten Jember

\begin{tabular}{lcccccc}
\hline \multirow{2}{*}{ Ketersediaan Mengonsumsi } & \multicolumn{3}{c}{ Jumlah (orang) } & \multicolumn{2}{c}{ Presentase (\%) } \\
\cline { 2 - 7 } & Risk & Risk & Risk & Risk & Risk & Risk \\
& Lover & Neutral & Averse & Lover & Neutral & Averse \\
\hline Bersedia Mengonsumsi & 67 & 4 & 26 & 83,75 & 40 & 43,33 \\
Tidak Bersedia Mengonsumsi & 13 & 6 & 34 & 16,25 & 60 & 56,67 \\
\hline Total & $\mathbf{8 0}$ & $\mathbf{1 0}$ & $\mathbf{6 0}$ & $\mathbf{1 0 0}$ & $\mathbf{1 0 0}$ & $\mathbf{1 0 0}$ \\
\hline
\end{tabular}

Sumber: Data Primer diolah (2019)

Tabel 7. Distribusi Risk Preference Mahasiswa Agroteknologi dalam Mengonsumsi Produk Rekayasa Genetika di Kabupaten Jember

\begin{tabular}{lcccccc}
\hline & \multicolumn{3}{c}{ Jumlah (orang) } & \multicolumn{3}{c}{ Presentase (\%) } \\
\cline { 2 - 7 } Ketersediaan Mengonsumsi & Risk & Risk & Risk & Risk & Risk & Risk \\
& Lover & Neutral & Averse & Lover & Neutral & Averse \\
\hline Bersedia Mengonsumsi & 15 & 7 & 0 & 88,23 & 87,5 & 0 \\
Tidak Bersedia Mengonsumsi & 2 & 1 & 15 & 11,67 & 12,5 & 100 \\
\hline Total & $\mathbf{2 6}$ & $\mathbf{6}$ & $\mathbf{8}$ & $\mathbf{1 0 0}$ & $\mathbf{1 0 0}$ & $\mathbf{1 0 0}$ \\
\hline
\end{tabular}

Sumber: Data Primer diolah (2019) 
Distribusi risk preference responden mahasiswa Fakultas Kesehatan Masyarakat dapat dilihat pada Tabel 8. Mahasiswa Fakultas Kesehatan Masyarakat yang memiliki sifat menyukai risiko didominasi oleh responden yang bersedia mengonsumsi produk rekayasa genetika sebanyak 21 orang atau 80,76\% sedangkan sisanya 5 orang atau 19,24\% memilih untuk tidak bersedia mengonsumsi produk rekayasa genetika.

Mahasiswa yang memiliki sifat netral terhadap risiko cenderung memilih untuk bersedia mengonsumsi produk rekayasa genetika sebanyak 4 orang atau $66,67 \%$ sedangkan 2 orang atau 33,33\% memilih untuk tidak bersedia mengonsumsi produk rekayasa genetika.

Distribusi risk preference responden mahasiswa agribisnis dapat dilihat pada Tabel 9. Mahasiswa agribisnis yang memiliki sifat menyukai risiko didominasi oleh responden yang bersedia mengonsumsi produk rekayasa genetika sebanyak 20 orang atau 83,33\% sedangkan 4 orang atau 16,67\% memilih untuk tidak bersedia mengonsumsi produk rekayasa genetika. Sebanyak 8 orang mahasiswa yang memiliki sifat netral terhadap risiko seluruhnya bersedia mengonsumsi produk rekayasa genetika.

Mahasiswa yang memiliki sifat menghindari risiko didominasi oleh responden yang tidak bersedia mengonsumsi produk rekayasa genetika sebanyak 7 orang atau $87,5 \%$ sedangkan 1 orang sisanya atau 12,5\% memilih untuk bersedia mengonsumsi produk rekayasa genetika.

Distribusi risk preference responden dosen dapat dilihat pada Tabel 10. Dosen yang memiliki sifat menyukai risiko mayoritas bersedia mengonsumsi produk rekayasa genetika yaitu sebanyak 11 orang atau $84,62 \%$ sedangkan 2 orang sisanya atau $15,38 \%$

Tabel 8. Distribusi Risk Preference Mahasiswa Fakultas Kesehatan Masyarakat dalam Mengonsumsi Produk Rekayasa Genetika di Kabupaten Jember

\begin{tabular}{lcccccc}
\hline \multirow{2}{*}{ Ketersediaan Mengonsumsi } & \multicolumn{3}{c}{ Jumlah (orang) } & \multicolumn{2}{c}{ Presentase (\%) } \\
\cline { 2 - 7 } & Risk & Risk & Risk & Risk & Risk & Risk \\
& Lover & Neutral & Averse & Lover & Neutral & Averse \\
\hline Bersedia Mengonsumsi & 21 & 4 & 7 & 80,76 & 66,67 & 87,5 \\
Tidak Bersedia Mengonsumsi & 5 & 2 & 1 & 19,24 & 33,33 & 12,5 \\
\hline Total & $\mathbf{2 6}$ & $\mathbf{6}$ & $\mathbf{8}$ & $\mathbf{1 0 0}$ & $\mathbf{1 0 0}$ & $\mathbf{1 0 0}$ \\
\hline Sumber: Data Primer diolah (2019) & & & & & &
\end{tabular}

Tabel 9. Distribusi Risk Preference Mahasiswa Agribisnis dalam Mengonsumsi Produk Rekayasa Genetika di Kabupaten Jember

\begin{tabular}{lcccccc}
\hline \multirow{2}{*}{ Ketersediaan Mengonsumsi } & \multicolumn{3}{c}{ Jumlah (orang) } & \multicolumn{3}{c}{ Presentase (\%) } \\
\cline { 2 - 7 } & $\begin{array}{c}\text { Risk } \\
\text { Lover }\end{array}$ & $\begin{array}{c}\text { Risk } \\
\text { Neutral }\end{array}$ & $\begin{array}{c}\text { Risk } \\
\text { Averse }\end{array}$ & $\begin{array}{c}\text { Risk } \\
\text { Lover }\end{array}$ & $\begin{array}{c}\text { Risk } \\
\text { Neutral }\end{array}$ & $\begin{array}{c}\text { Risk } \\
\text { Averse }\end{array}$ \\
\hline Bersedia Mengonsumsi & 20 & 8 & 1 & 83,33 & 100 & 12,5 \\
Tidak Bersedia Mengonsumsi & 4 & 0 & 7 & 16,67 & 0 & 87,5 \\
\hline Total & $\mathbf{2 4}$ & $\mathbf{8}$ & $\mathbf{8}$ & $\mathbf{1 0 0}$ & $\mathbf{1 0 0}$ & $\mathbf{1 0 0}$ \\
\hline Sumber: Data Primer diolah (2019) & & & & & &
\end{tabular}

Tabel 10. Distribusi Risk Preference Dosen dalam Mengonsumsi Produk Rekayasa Genetika di Kabupaten Jember

\begin{tabular}{lcccccc}
\hline & \multicolumn{3}{c}{ Jumlah (orang) } & \multicolumn{3}{c}{ Presentase (\%) } \\
\cline { 2 - 7 } Ketersediaan Mengonsumsi & Risk & Risk & Risk & Risk & Risk & Risk \\
& Lover & Neutral & Averse & Lover & Neutral & Averse \\
\hline Bersedia Mengonsumsi & 11 & 6 & 3 & 84,62 & 60 & 42,86 \\
Tidak Bersedia Mengonsumsi & 2 & 4 & 4 & 15,38 & 40 & 57,14 \\
\hline Total & $\mathbf{1 3}$ & $\mathbf{1 0}$ & $\mathbf{7}$ & $\mathbf{1 0 0}$ & $\mathbf{1 0 0}$ & $\mathbf{1 0 0}$ \\
\hline
\end{tabular}

Sumber: Data Primer diolah (2019) 
memilih untuk tidak bersedia mengonsumsi produk rekayasa genetika. Sebanyak 6 orang atau $60 \%$ yang memiliki sifat netral terhadap risiko memilih untuk bersedia mengonsumsi produk rekayasa genetika dan sisanya 4 orang atau $40 \%$ memilih untuk tidak bersedia mengonsumsi produk rekayasa genetika. Dosen yang memiliki sifat menghindari risiko cenderung memilih untuk tidak bersedia mengonsumsi produk rekayasa genetika sebanyak 4 orang atau $57,14 \%$ dan sisanya sebanyak 3 orang atau $42,86 \%$ memilih untuk bersedia mengonsumsi produk rekayasa genetika.

Berdasarkan hasil analisis, tidak ada perbedaan sifat dalam menghadapi risiko antar empat kelompok yang diteliti. Hasil dari keempat kelompok yaitu mahasiswa agribisnis, agroteknologi dan kesehatan masyarakat serta dosen mayoritas didominasi oleh responden yang memiliki sifat menyukai risiko. Responden yang memiliki sifat menyukai risiko mayoritas memilih untuk bersedia mengonsumsi PRG. Hal tersebut dikarenakan responden lebih menyukai memilih untuk mendapat keuntungan yang besar meskipun ada potensi untuk mendapat kerugian yang besar pula daripada memilih untuk mendapat hasil yang pasti tetapi hanya sedikit. Karena adanya PRG dapat meningkatkan ketersediaan pangan sehingga tidak kesulitan untuk mencari bahan pangan.

\section{FAKTOR-FAKTOR YANG MEMPENGARUHI PENGAMBILAN KEPUTUSAN MASYARAKAT ILMIAH DALAM MENGONSUMSI PRODUK REKAYASA GENETIKA DI KABUPATEN JEMBER}

Permasalahan ketersediaan pangan saat ini menjadi masalah yang dihadapi oleh negara berkembang. Salah satu cara untuk mengatasi permasalahan tersebut adalah dengan rekayasa genetika. Rekayasa genetik bertujuan memodifikasi gen dari suatu tanaman agar memiliki keunggulan. Tetapi sampai saat ini keberadaan dari PRG masih menimbulkan kontroversi, dikarenakan dam- pak dari PRG masih belum diketahui. Variabel yang diduga menjadi faktor yang mempengaruhi keputusan masyarakat ilmiah dalam mengonsumsi PRG di Kabupaten Jember antara lain Jenis Pekerjaan $\left(\mathrm{D}_{1}\right)$, Jenis Kelamin $\left(D_{2}\right)$, Usia $\left(X_{1}\right)$, Jumlah Uang Saku atau Pendapatan per Bulan (X2), Pengeluaran untuk Kebutuhan Pangan per Hari $\left(\mathrm{X}_{3}\right)$, Tingkat Pengetahuan $\left(\mathrm{X}_{4}\right)$ dan Risk Aversion Level $\left(\mathrm{X}_{5}\right)$. Beberapa kriteria pengujian yang harus dipenuhi untuk menilai keseluruhan serta kesesuaian model tersebut dapat diinterpretasikan seperti terlihat pada Tabel 11.

Tabel 11. Hasil Analisis Regresi Logistik

\begin{tabular}{lcc}
\hline \multicolumn{1}{c}{ Output } & Signifikansi & Nilai \\
\hline Omnimbus Test of & & \\
Model Coefficient & 0,000 & 76,567 \\
Nagelkerke R Square & 0,000 & 0,550 \\
-2 Log Likelihood (step 0) & 0,000 & 194,846 \\
-2 Log Likelihood (step 1) & 0,000 & 118,279 \\
Classification Table & 0,000 & $86,7 \%$ \\
Hosmer and Lemeshow's & 0,333 & 9,109 \\
\hline
\end{tabular}

Sumber: Data Primer diolah (2019)

Berdasarkan Tabel 11 diketahui bahwa hasil analisis regresi logistik menunjukkan nilai Chi-Square (G-hitung) sebesar 76,567 dengan nilai signifikansi sebesar 0,000 yang berarti dengan taraf kepercayaan 99\% terdapat minimal satu variabel independen yang berpengaruh secara signifikan terhadap variabel dependen. Nilai Nagelkerke $R$ Square sebesar 0,550 yang menunjukkan bahwa kemampuan variabel independen dalam model mampu menjelaskan variabel dependennya sebesar 55,5\%. Nilai statistik -2 log likelihood pada Blok 0 yakni sebesar 194,846 menjadi 118,279 pada nilai statistik Blok 1 menunjukkan bahwa adanya penambahan variabel independen dapat memperbaiki model. Hasil analisis pada output classification table sebesar $86,7 \%$ menggambarkan bahwa model persamaan yang digunakan untuk analisis sudah layak karena dapat menduga kondisi real di lokasi penelitian untuk mengetahui keputusan masyarakat ilmiah dalam mengonsumsi PRG memiliki tingkat akurasi sebesar 
86,7\%. Nilai signifikansi output Hosmer and Lemeshow's Goodness of Fit Test sebesar 0,333 berarti bahwa model persamaan regresi logistik yang digunakan baik dan layak untuk dipakai pada analisis selanjutnya sebab tidak ada perbedaan signifikan antara model dengan nilai observasinya.

Uji Wald merupakan uji signifikansi secara parsial atau individu untuk mengetahui pengaruh masing-masing variabel independen terhadap variabel dependen. Hasil Uji Wald di jelaskan pada Tabel 12. Variabel indepeden dinyatakan berpengaruh dalam pengambilan keputusan masyarakat ilmiah dalam mengonsumsi produk rekayasa genetika apabila nilai signifikansi yang diperoleh lebih kecil dari taraf kesalahan $(0,1)$.

\section{Usia $\left(X_{1}\right)$}

Berdasarkan hasil analisis regresi logistik didapatkan variabel usia memiliki nilai signifikansi sebesar 0,012 sehingga variabel usia berpengaruh nyata terhadap pengambilan keputusan masyarakat ilmiah mengonsumi produk rekayasa genetika.

Nilai koefisien (b) variabel usia sebesar 0,230 . Artinya jika usia masyarakat ilmiah bertambah 1 tahun, maka akan meningkatkan peluang keputusan untuk mengonsumsi produk rekayasa genetika sebesar 0,230 . Nilai Odd Ratio $(\operatorname{Exp}(\mathrm{B}))$ variabel usia sebesar 1,259 berarti bahwa tiap penambahan usia 1 tahun maka memiliki peluang lebih tinggi untuk mengonsumsi produk rekayasa genetika sebesar 1,278 dibandingkan dengan masyara- kat ilmiah yang usianya 1 tahun dibawahnya. Hasil tersebut didukung oleh penelitian yang dilakukan oleh (Loureiro et al., 2002) bahwa ketika usia konsumen bertambah satu tahun, maka akan menurunkan peluang konsumen dalam kesediaannya untuk membayar lebih pada produk bebas GMO.

\section{Tingkat Pengetahuan $\left(X_{2}\right)$}

Berdasarkan hasil analisis regresi logistik didapatkan variabel tingkat pengetahuan memiliki nilai signifikansi sebesar 0,019 sehingga variabel tingkat pengetahuan berpengaruh nyata terhadap pengambilan keputusan masyarakat ilmiah mengonsumi produk rekayasa genetika.

Nilai koefisien (b) variabel tingkat pengetahuan sebesar $-0,662$. Artinya, jika tingkat pengetahuan masyarakat ilmiah bertambah sebesar 10 poin, maka akan menurunkan peluang keputusan untuk mengonsumsi produk rekayasa genetika sebesar 0,62.

Nilai Odd Ratio $(\operatorname{Exp}(\mathrm{B}))$ variabel tingkat pengetahuan per hari sebesar 0,516 berarti bahwa tiap penambahan tingkat pengetahuan 10 poin maka memiliki peluang lebih tinggi untuk tidak mengonsumsi produk rekayasa genetika sebesar 0,516 dibandingkan dengan masyarakat ilmiah yang tingkat pengetahuan 10 poin dibawahnya. Hasil tersebut didukung oleh penelitian yang dilakukan oleh (Artanti et al., 2010) bahwa semakin tinggi tingkat pengetahuan, maka akan semakin rendah tingkat penerimaan petani terhadap produk rekayasa genetika.

Tabel 12. Output Variable in the Equation pada Model Logistik Mengenai Pengambilan Keputusan Masyarakat Ilmiah dalam Mengonsumsi Produk Rekayasa Genetika

\begin{tabular}{lcccccc}
\hline \multicolumn{1}{c}{ Variabel } & B & S.E. & Wald & dF & Sig. & Exp(B) \\
\hline Usia $\left(\mathrm{X}_{1}\right)$ & 0,230 & 0,091 & 6,344 & 1 & 0,012 & 1,259 \\
Tingkat Pengetahuan $\left(\mathrm{X}_{2}\right)$ & $-0,631$ & 0,269 & 5,500 & 1 & 0,019 & 0,532 \\
Pengeluaran Pangan per Hari $\left(\mathrm{X}_{3}\right)$ & $-0,061$ & 0,022 & 7,519 & 1 & 0,006 & 0,941 \\
Jumlah Uang Saku atau Pendapatan per & & & & & & \\
Bulan $\left(\mathrm{X}_{4}\right)$ & $-0,006$ & 0,003 & 4,799 & 1 & 0,028 & 0,994 \\
Risk Aversion Level $\left(\mathrm{X}_{5}\right)$ & $-1,667$ & 0,330 & 25,480 & 1 & 0,000 & 0,189 \\
Jenis Kelamin $\left(\mathrm{D}_{1}\right)$ & $-0,328$ & 0,483 & 0,462 & 1 & 0,497 & 0,720 \\
Jenis Pekerjaan $\left(\mathrm{D}_{2}\right)$ & 2,483 & 1,275 & 3,795 & 1 & 0,051 & 11,978 \\
Constant & 4,947 & 1,934 & 6,544 & 1 & 0,011 & 146,711 \\
\hline
\end{tabular}

Sumber: Data Primer diolah (2019) 
3. Variabel Pengeluaran Pangan per Hari $\left(X_{3}\right)$

Berdasarkan hasil analisis regresi logistik didapatkan variabel pengeluaran pangan per hari memiliki nilai signifikansi sebesar 0,006 sehingga variabel pengeluaran pangan per hari berpengaruh nyata terhadap pengambilan keputusan masyarakat ilmiah mengonsumsi produk rekayasa genetika.

Nilai koefisien (b) variabel pengeluaran pangan per hari sebesar -0,061. Artinya, jika pengeluaran pangan per hari masyarakat ilmiah bertambah Rp 1.000, maka akan menurunkan peluang keputusan untuk mengonsumsi produk rekayasa genetika sebesar 0,065. Nilai Odd Ratio $(\operatorname{Exp}(\mathrm{B}))$ variabel pengeluaran pangan per hari sebesar 0,937 berarti bahwa tiap penambahan pengeluaran pangan per hari Rp 1.000 maka memiliki peluang lebih tinggi untuk tidak mengonsumsi produk rekayasa genetika sebesar 0,937 dibandingkan dengan masyarakat ilmiah yang pengeluaran pangan per hari Rp 1.000 dibawahnya. Hal itu dikarenakan responden yang pengeluaran pangan per harinya makin tinggi lebih mementingkan keamanan pangan daripada mengonsumsi barang yang masih memiliki risiko

\section{Jumlah Uang Saku atau Pendapatan per Bulan $\left(\mathbf{X}_{4}\right)$}

Berdasarkan hasil analisis regresi logistik didapatkan variabel jumlah uang saku atau pendapatan per bulan memiliki nilai signifikansi sebesar 0,028 sehingga variabel jumlah uang saku atau pendapatan per bulan berpengaruh nyata terhadap pengambilan keputusan masyarakat ilmiah mengonsumsi produk rekayasa genetika.

Nilai koefisien (b) variabel jumlah uang saku atau pendapatan per bulan sebesar $-0,006$. Artinya, jika jumlah uang saku atau pendapatan per bulan masyarakat ilmiah bertambah Rp 10.000, maka akan menurunkan peluang keputusan untuk mengonsumsi produk rekayasa genetika sebesar 0,006 . Nilai Odd Ratio $(\operatorname{Exp}(\mathrm{B}))$ variabel jumlah uang saku atau pendapatan per bulan sebesar 0,994 berarti bahwa tiap penambahan jumlah uang saku atau pendapatan per bulan Rp 10.000 maka memiliki peluang lebih tinggi untuk tidak mengonsumsi produk rekayasa genetika sebesar 0,994 dibandingkan dengan masyarakat ilmiah yang jumlah uang saku atau pendapatan per bulan Rp 10.000 dibawahnya. Hasil tersebut sesuai dengan penelitian yang dilakukan oleh (Loureiro et al., 2002) bahwa ketika semakin tinggi pendapatan maka akan meningkatkan peluang konsumen dalam kesediaannya untuk membayar lebih pada produk bebas GMO.

\section{Risk Aversion Level $\left(\mathrm{X}_{5}\right)$}

Berdasarkan hasil analisis regresi logistik didapatkan variabel risk aversion level memiliki nilai signifikansi sebesar 0,000 sehingga variabel risk aversion level berpengaruh nyata terhadap pengambilan keputusan masyarakat ilmiah mengonsumi produk rekayasa genetika.

Nilai koefisien (b) variabel risk aversion level sebesar $-1,698$. Artinya, jika risk aversion level masyarakat ilmiah bertambah sebesar 1 tingkat, maka akan menurunkan peluang keputusan untuk mengonsumsi produk rekayasa genetika sebesar 1,698.

Nilai Odd Ratio $(\operatorname{Exp}(\mathrm{B}))$ variabel pengeluaran pangan per hari sebesar 0,183 berarti bahwa tiap penambahan risk aversion level sebanyak 1 tingkat maka memiliki peluang lebih tinggi untuk tidak mengonsumsi produk rekayasa genetika sebesar 0,183 dibandingkan dengan masyarakat ilmiah yang risk aversion level 1 tingkat dibawahnya. Hasil tersebut sesuai dengan penelitian yang dilakukan oleh Baker dan Burnham (2001) bahwa risk aversion level menjadi salah satu faktor penting yang mempengaruhi perilaku masyarakat terhadap produk GMO yang beredar. Semakin tinggi tingkat risk aversion level konsumen maka semakin besar kemungkinan untuk tidak menerima produk rekayasa genetika.

\section{Jenis Kelamin $\left(D_{1}\right)$}

Nilai signifikansi yang dimiliki variabel jenis kelamin lebih besar dibandingkan taraf kesalahan $(0,497>0,1)$. Perbedaan jenis kelamin bukan menjadi variabel signifikan dalam mempengaruhi keputusan dalam mengonsumsi produk rekayasa genetika. Hasil tersebut didukung oleh penelitian yang dilakukan oleh Subandi (2008) yang menyata- 
kan bahwa variabel jenis kelamin tidak berpengaruh nyata dalam penerimaan produk transgenik pringles.

\section{Jenis Pekerjaan $\left(D_{2}\right)$}

Hasil analisis regresi logistik menyatakan secara statistik variabel jenis pekerjaan berpengaruh secara nyata terhadap pengambilan keputusan masyarakat ilmiah dalam mengonsumsi produk rekayasa genetika. Nilai koefisien (b) variabel jenis pekerjaan sebesar 2,483 dan nilai Odd Ratio $(\operatorname{Exp}(\mathrm{B}))$ sebesar 11,978. Memiliki makna bahwa jenis pekerjaan dosen akan meningkatkan peluang masyarakat ilmiah dalam mengonsumsi produk rekayasa genetika sebesar 2,483. Peluang masyarakat ilmiah yang memiliki pekerjaan sebagai dosen akan memilih untuk mengonsumsi produk rekayasa genetika adalah sebesar 2,483 kali lebih tinggi dibanding masyarakat ilmiah yang jenis pekerjaannya mahasiswa dengan asumsi ceteris paribus.

Hal ini dikarenakan wawasan yang dimiliki oleh dosen lebih luas dibandingkan dengan mahasiswa. Mahasiswa masih terpengaruh oleh stereotip negatif terkait dampak dari mengonsumsi produk rekayasa genetika. Sebaliknya, dosen sudah lebih banyak mengetahui tentang produk rekayasa genetika dan mengakui bahwa mayoritas produk yang beredar sekarang adalah produk rekayasa genetika.

\section{KESIMPULAN DAN SARAN}

\section{KESIMPULAN}

1. Persepsi masyarakat ilmiah secara keseluruhan terhadap produk rekayasa genetika berdasarkan aspek kesehatan dan lingkungan pertanian adalah setuju. Hal itu karena dampak positif yang dirasakan sangat besar, antara lain meningkatkan ketersediaan pangan dan peningkatan kandungan nutrisi pada tanaman. Persepsi berdasarkan aspek ekonomi masih raguragu karena masyarakat ilmiah masih belum meyakini adanya PRG akan memberikan harga yang lebih murah
2. Preferensi risiko masyarakat ilmiah berdasarkan empat kelompok yaitu mahasiswa agribisnis, agroteknologi dan kesehatan masyarakat serta dosen mayoritas memiliki sifat menyukai risiko. Hal itu karena adanya PRG memberikan dampak positif yang besar antara lain meningkatkan ketersediaan pangan, meskipun PRG merupakan barang yang berisiko

3. Faktor-faktor yang berpengaruh secara positif atau meningkatkan peluang masyarakat ilmiah untuk mengonsumsi PRG yaitu variabel jenis pekerjaan dan usia. Faktor yang berpengaruh secara negatif atau menurunkan peluang masyarakat ilmiah untuk mengonsumsi PRG adalah variabel jumlah uang saku atau pendapatan per bulan, pengeluaran pangan per hari, tingkat pengetahuan dan risk aversion level.

\section{SARAN}

1. Mayoritas masyarakat ilmiah bersifat risk lover atau menyukai risiko dan cenderung bersedia mengonsumsi produk rekayasa genetika. Hal tersebut terjadi dikarenakan responden masih belum bisa membedakan antara PRG dan non-PRG secara fisik. Sehingga perlunya labelling terhadap suatu produk untuk membedakan PRG dengan non-PRG.

2. Penelitian ini dapat dikembangkan lebih lanjut dengan mengangkat topik terkait tingkat penerimaan produk rekayasa genetika.

\section{DAFTAR PUSTAKA}

Artanti, G. D., Hardinsyah, D. K. S. Swastika, dan Retnaningsih. 2010. Analisis FaktorFaktor Yang Mempengaruhi Penerimaan Petani Terhadap Produk Rekayasa Genetika. Gizi dan Pangan 5(2): 113-20.

Baker, G. A., dan T. A. Burnham. 2001. Consumer Response to Genetically Modified Foods: Market Segment Analysis dan Implications for Producers 
and Policy Makers. Journal of Agricultural dan Resource Economics 26(2): 387-403.

Bennet, J. W. 1998. Mycotechnology: The Role of Fungi in Biotechnology. Journal of Biotechnology 66(1):101-107.

Blair, E., dan K. Inniss. 2011. Student evaluation questionnaires and the developing world: An examination of the move from a hard copy to online modality. Studies in Educational Evaluation 40 (2014): 36-42.

Carletto, C., A. Zezza, dan R. Banerjee. 2013. Towards Better Measurement of Household Food Security : Harmonizing Indicators dan the Role of Household Surveys. Global Food Security 2(1): 30-40.

Hidayat, Y. R. 2014. Persepsi Masyarakat terhadap Tanaman Transgenik di Kabupaten Cirebon. Jurnal Agrijati. 26(1): 1-14

Holt, C. A., dan S. K. Laury. 1980. Risk Aversion dan Incentive Effects. The American Economic Review 92(5): 16441655.

ISAAA. 2017. 22 Years of Biotech Crops in the World. Diunduh tanggal 20 Desember 2018 dari www.isaaa.org

ISAAA. 2017. Global Status of Commercialized Biotech/GM Crops in 2017: Biotech Crop Adoption Surges as Economic Benefits Accumulate in 22 Years. Manila. Diunduh tanggal 20 Desember 2018 dari www.isaaa.org

Loureiro, M, L., dan S. Hine. 2002. Economics : Discovering Niche Markets: A Comparison of Consumer Willingness to Pay for Local (Colorado Grown), Organic dan GMO-Free Products Discovering Niche Markets: A Comparison of Consumer Willingness to Pay for Local (Colorado Grown), Organic. Journal of Agricultural and Applied Economics 55(1): 477-87.

Messeguer, J. 2003. Gene Flow Assesment in Transgenic Plants. Plant Cell, Tissue and Organ Culture 73(1): 201-212.
Mulyani, A., D. Kuncoro, D. Nursyamsi, dan F. Agus. 2016. Modern Invention of the Sanscrit Alphabet. Tanah dan Iklim 40(2): 329-30.

Prasifka, P. L., R. L. Hellmich, J. R. Prasifka dan L. C. Lewis. 2007. Effect of CryaAbExpressing Corn Anthers on the Movement of Monarch Butterfly Larvae. Transgenic Plant and Insect 36(1):1-6.

Prianto, Y. dan S. Yudhasasmita. 2017. Tanaman Genetically Modified Organism (GMO) dan Perspektif Hukumnya di Indonesia. Journal of Biology 10(2): 133-142.

Saragih, E. S., S. R. P. Sitorus, Harianto dan S. Moeljopawiro. 2009. Analisis Kelayakan Ekonomi, Keberlanjutan Usahatani dan Faktor-Faktor Penentu Adopsi Benih Jagung Transgenik di Indonesia. Agro Ekonomi. 27(1): 23-44.

Setiawan, A., A. M. Disrinaman, U. Priastuti, dan N A. Novitrie. 2018. Sosialisasi Dampak Pemakaian Bahan Kimia Rumah Tangga Dan Bahan Aditif Makanan Terhadap Kesehatan Keluarga. Cakrawala Maritim: 15-20.

Shew, A. M., L. L. Nalley, D. M. Danforth, B. L. Dixon, R. M. Nayga, A. C. Delwade dan B. Valent. 2016. Are All GMOs the Same? Consumer Acceptance of Cisgenic Rice in India. Plant Biotechnology Journal 14(1): 4-7.

Siregar, F. ST., S. Andasyari dan T. D. Ansar. 2012. Rekayasa Genetik: Manfaat dan Dampak Negatifnya Terhadap Kehidupan Manusia. Rekayasa Genetika 1(1): 1-12.

Slette, J. dan T. Rahayu. 2013. Agricultural Biotechnology Annual. GAIN Report 1(1): 1-15.

Smith, J. 10 Reasons to Avoid GMOS. 2011. Diakses pada tanggal 9 November 2019 dari http:// responsibletechnology.org/ 10-reasons-to-avoid-gmos. Diakses pada tanggal 9 November 2019. 
Subandi, Baban. 2008. Pengetahuan Dan

Penerimaan Konsumen Berpendapatan Tinggi Di Bogor Terhadap Keripik Kentang [Skripsi]. Bogor: Program Sarjana Eksistensi Manajemen Agribisnis Institut Pertanian Bogor. 